\title{
Tuning Catalytic Activity of Dimolybdenum Paddlewheel Complexes by Ligands:Mechanism Study on the Radical Addition Reaction of CCl4 to 1- Hexene
}

\author{
Ling Wang \\ Hebei Normal University \\ Lixia Kang \\ Hebei Normal University \\ Suhong Huo \\ North China University of Science and Technology \\ Xueying Zhang \\ Hebei Normal University \\ Xiaoyan Li ( $\square$ lixiaoyan@hebtu.edu.cn ) \\ Hebei Normal University https://orcid.org/0000-0003-2819-5420
}

\section{Research Article}

Keywords: dimolybdnum paddlewheel complex, metal-metal quadruply-bond, radical addition, catalytic activity, ligand effect

Posted Date: April 2nd, 2021

DOI: https://doi.org/10.21203/rs.3.rs-363576/v1

License: (c) (i) This work is licensed under a Creative Commons Attribution 4.0 International License.

Read Full License

Version of Record: A version of this preprint was published at Structural Chemistry on April 26th, 2021. See the published version at https://doi.org/10.1007/s11224-021-01790-2. 


\section{Abstract}

The detailed catalytic mechanism of a series of paddlewheel complexes $\left[\mathrm{Mo}_{2} \mathrm{~L}_{4}\right]$ featuring Mo-Mo quadruply-bond on radical addition of $\mathrm{CCl}_{4}$ to 1-hexene was studied using density functional theory. Different ligands of Mo-Mo bond are investigated to illustrate the ligand effect on the catalytic activity. The results show that the Mo-Mo quadruply-bond paddlewheel complexes have high catalytic activity on the title reaction. The whole reaction involves 4 steps. Firstly, the $\mathrm{C}-\mathrm{Cl}$ bond of first $\mathrm{CCl}_{4}$ is activated by $\left[\mathrm{Mo}_{2} \mathrm{~L}_{4}\right]$ catalyst, $\left[\mathrm{Mo}_{2} \mathrm{~L}_{3} \mathrm{Cl}\right]$ and $\mathrm{CH}_{3} \mathrm{COOCCl}_{3}$ are obtained; Then the second $\mathrm{CCl}_{4}$ adds to $\left[\mathrm{Mo}_{2} \mathrm{~L}_{3} \mathrm{Cl}\right]$ to produce $\left[\mathrm{Mo}_{2} \mathrm{~L}_{3} \mathrm{Cl}_{2}\right]$ and $\mathrm{CCl}_{3}$ radical; $\mathrm{CCl}_{3}$ radical interacts with 1-hexene to get an addition, the addition product which reacts with one $\mathrm{Cl}$ atom of $\left[\mathrm{Mo}_{2} \mathrm{~L}_{3} \mathrm{Cl}_{2}\right]$ to get the last product ${ }^{\mathrm{n}} \mathrm{BuCHClCH}_{2} \mathrm{CCl}_{3}$ and regenerate $\left[\mathrm{Mo}_{2} \mathrm{~L}_{3} \mathrm{Cl}\right]$. The addition of the first $\mathrm{CCl}_{4}$ to $\left[\mathrm{Mo}_{2} \mathrm{~L}_{4}\right]$ catalyst is the rate-determining step of the whole reaction. Because this step is not in the catalytic cycle, the reaction would speed up after a certain period of time. The catalytic activity of dimolybdenum paddlewheel complex is depended on the natural population analysis (NPA) charge of Mo and the redox potential $\mathrm{E}\left(\mathrm{Mo}_{2}{ }^{4+} / \mathrm{Mo}_{2}{ }^{5+}\right)$. The higher NPA of Mo atom and higher $\mathrm{E}\left(\mathrm{Mo}_{2}{ }^{4+} / \mathrm{Mo}_{2}{ }^{5+}\right)$ of the catalyst, the higher catalytic activity it has. Our calculated results provide an explanation for experimental observations and useful insights for further development of bimetallic catalysts in radical addition reactions.

\section{Introduction}

Since the first dimolybdenum complex (molybdenum(II) acetate) containing Mo-Mo multiple bond was isolated and characterized [1], a large number of polymetal-metal bonding complexes have been synthesized [2-8]. In particular, the metal-metal bonded compounds with unique paddlewheel structures have played a major role in development of coordination chemistry [9] and continue to be of interest for their catalytic [10], photophysical [11], electronic [12], and structural properties[13] as well as reactivity $[14,15]$. Among these paddlewheel compounds, dimolybdenum compounds (denotes as $\mathrm{Mo}_{2} \mathrm{~L}_{4}$ ) have attracted much more attention due to their unique configuration and catalytic applications [16-21]. The $\mathrm{Mo}_{2} \mathrm{~L}_{4}$ paddlewheel compounds possess a quadruple metal-metal bond $\left(\sigma^{2} \pi^{4} \delta^{2}\right)$ supported by four bridging ligands, such as carboxylates, amides, pyrrolidinates, etc [2, 22-24]. These compounds exhibits one-electron redox properties in radical transformation processes, which can result in reductively cleaving a carbon-halogen bond in organic halides to generate organic radicals $[2,4,18,24-26]$.

The study of $\mathrm{K}$. Mashima et al showed that $\mathrm{Mo}_{2}(\mathrm{OCOAr})_{4}\left(\mathrm{Ar}=2,4,6-{ }^{-} \mathrm{Pr}_{3} \mathrm{C}_{6} \mathrm{H}_{2}\right)$ was used for a catalytic radical addition reaction of $\mathrm{CCl}_{4}$ to 1-hexene in $\mathrm{THF}-\mathrm{d}_{8}$ at $80^{\circ} \mathrm{C}$ to give 1, 1, 1, 3-tetrachloroheptane regioselectively in $84 \%$ yield. They also found that the redox properties of $\left[\mathrm{Mo}_{2}\right]$ complexes are changed by replacing the ligands, the catalytic activity for the radical addition reaction strongly depended on the redox potential of the $\left[\mathrm{Mo}_{2}\right.$ ] complexes [4]. N. J. Patmore found that the electronic structure of Mo-Mo quadruple bonds can be tuned through $\mathrm{O} / \mathrm{S}$ substitution of $\mathrm{N}$ by lowering the $\mathrm{HOMO}$ energy of $\mathrm{MO}_{2}$ and reducing the $\mathrm{Mo}_{2}{ }^{4+/ 5+}$ oxidation potential [27]. 
In 2017, Mashima K. et al synthesized a series of mixed ligated tris(amidinate) dimolybdenum complexes as catalysts for radical addition of $\mathrm{CCl}_{4}$ to 1-hexene [24]. Their experimental investigation showed that the nature of the $L$ ligands was a crucial factor for initiating the catalytic reaction. Rational catalytic cycle of radical addition reaction catalyzed by $\left[\mathrm{Mo}_{2}(\mathrm{DAniF})_{3}\left(\mathrm{OCO}\left(\mathrm{CH}_{3}\right)\right)\right]\left(\mathrm{DAniF}=\mathrm{CH}_{3} \mathrm{NCHNCH}_{3}\right)$ is proposed (Scheme 1). The catalytic activities of series of mixed-ligated dimolybdenum complexes are higher than those of homoleptic $\mathrm{Mo}_{2}$ complexes [24].

In this work, the addition reaction between $\mathrm{CCl}_{4}$ and 1-hexene catalysed by a series of quadruple-bonded dimolybdenum complexes are investigated based on density functional theory. The aims of this work are (1) to illustrate the addition reaction mechanism of $\mathrm{CCl}_{4}$ and 1-hexene catalysed by the quadruple-bonded dimolybdenum complexes; (2) to determine how the ligand tuning the catalytic activity of $\mathrm{Mo}_{2} \mathrm{~L}_{4}$ and (3) to screen out the ligands of $\mathrm{Mo}_{2} \mathrm{~L}_{4}$ with high activity. We seek to provide theoretical prediction for the catalytic activity of quadruple-bonded dimolybdenum paddlewheel complexes on radical addition reaction and to inspire the future applications in organic syntheses.

\section{Computational Details}

All of the calculations were performed at PBEPBE-D3 [28-29]/Def2-SVP[30, 31] level using Gaussian 09 package [32]. A functional, including dispersion correction [33, 34], has been proven that it can provide accurate energies for transition metals [35]. The vibrational frequency calculations were calculated at the same level to confirm the stable structure has no and the transition state has only one imaginary frequency. Intrinsic reaction coordinate (IRC) $[36,37]$ was calculated to confirm the linkage relationship between the transition states and stable points. In order to characterize the chemical bond changes in the reaction pathway, the Wiberg bond index and natural population charge were also obtained at the PBEPBE/Def2-SVP level using NBO 3.1 program [38].

\section{Results And Discussion}

\subsection{Catalytic Mechanism of $\mathrm{Mo}_{2}\left(\mathrm{CH}_{3} \mathrm{NCHNCH}_{3}\right)_{3}\left(\mathrm{OCOCH}_{3}\right)$ (denoted as CAT) on title reaction}

Based on the catalytic cycle for addition reaction of $\mathrm{CCl}_{4}$ to 1-hexene catalysed by CAT (Scheme 1), the catalytic mechanism has been calculated and determined. This transformation involves 4 steps. Firstly, the $\mathrm{C}-\mathrm{Cl}$ bond of first $\mathrm{CCl}_{4}$ is activated by $\mathrm{CAT}$, $\left[\mathrm{Mo}_{2} \mathrm{~L}_{3} \mathrm{Cl}\right]\left(\mathrm{L}=\mathrm{CH}_{3} \mathrm{NCHNCH}_{3}\right)$ and $\mathrm{CH}_{3} \mathrm{COOCCl}_{3}$ are obtained; Then the second $\mathrm{CCl}_{4}$ adds to $\mathrm{Mo}_{2} \mathrm{~L}_{3} \mathrm{Cl}$ to produce $\left[\mathrm{Mo}_{2} \mathrm{~L}_{3} \mathrm{Cl}_{2}\right]$ and $\mathrm{CCl}_{3}$ radical; $\mathrm{CCl}_{3}$ radical interacts with 1-hexene to carry out another addition reaction, and $\mathrm{Cl}$ atom migrates from $\left[\mathrm{Mo}_{2} \mathrm{~L}_{3} \mathrm{Cl}_{2}\right]$ to get product 1,1,1,3-tetrachloroheptane ${ }^{n} \mathrm{BuCHClCH}_{2} \mathrm{CCl}_{3}$ and $\left[\mathrm{Mo}_{2} \mathrm{~L}_{3} \mathrm{Cl}\right]$ is regenerated. The optimized geometries of the catalyst, reactants, complexes (COM), transition states (TS), and products are shown in Fig. 1, with the main parameters labelled on the geometries. The optimized xyz coordinates for the stationary points are given in Table S1-S22 (Supporting Information). The potential energy surfaces of the $\mathrm{C}$-Cl bond 
activation are shown in Fig. 2 and those of the addition reactions in Fig. 3. For convenience, the total energy of the reactants of each step is taken as the reference zero of energy.

First $\mathrm{C}$ - $\mathrm{Cl}$ bond activation: At the beginning of the reaction between CAT and $\mathrm{CCl}_{4}$, the $\mathrm{Cl}$ of $\mathrm{CCl}_{4}$ firstly interacts with one of the Mo atom of CAT to form COM1. In COM1, the two Mo atoms and two 0 atoms are in the same plane $\left(D_{\text {Mo-Mo-0-0 }}=0^{\circ}\right)$, the bond length of Mo-O bond near the $\mathrm{CCl}_{4}$ is $2.137 \AA$. As the reaction proceeding, the $\mathrm{Cl}$ atom goes near to the Mo atom. At the same time, the $\mathrm{O}$ atom of $\mathrm{OCOCH}_{3}$ ligand is pushed to leave away the Mo atom. In TS1, the distance between Mo and $\mathrm{Cl}$ decreases from $3.506 \AA$ to $2.618 \AA$, the Mo-O bond length increases to $3.128 \AA$, which means that Mo-O bond is broken. After TS1, the $\mathrm{C}-\mathrm{Cl}$ bond of $\mathrm{CCl}_{4}$ elongates gradually and the $\mathrm{OCOCH}_{3}$ ligand leaves away the Mo atom, the $\mathrm{D}_{\mathrm{Mo}-\mathrm{Mo-0}-0}=-73.8^{\circ}$ in $\mathrm{COM} 2$. Through $\mathrm{TS} 2$, the $\mathrm{CCl}_{3}$ and $\mathrm{OCOCH}_{3}$ leave away the $\left[\mathrm{Mo}_{2}\right]$ group and interact with each other to form $\mathrm{CH}_{3} \mathrm{OOCCl}$ and $\left[\mathrm{Mo}_{2}\left(\mathrm{CH}_{3} \mathrm{NCHNCH}_{3}\right)_{3} \mathrm{Cl}\right](\mathrm{PCl})$. In PCl, the $\mathrm{Cl}$ atom is above the Mo-Mo bond, and the two $\mathrm{Mo}-\mathrm{Cl}$ bonds are just the equal.

The potential energy surface of this step reaction is shown in Fig. 2(1). The energy barrier ( $\left.\Delta G^{\#}\right)$ of TS1 is $20.8 \mathrm{kcal} / \mathrm{mol}$ and that of TS2 is $21.0 \mathrm{kcal} / \mathrm{mol}$, the energy barriers are not high, thus, this step could happen at mild conditions. Our calculated $\Delta \mathrm{G}^{\#}$ is slightly smaller than that determined by kinetic experimental results, $26.0 \mathrm{kcal} / \mathrm{mol}$ at $303 \mathrm{~K}$ [24]. The experimental value is larger because it is determined in the presence of excess $\mathrm{CCl}_{4}$ and pyridine; the coordination of pyridine suppresses the reaction, which has been found in former studies [2, 8]. In this step, the changes of Mo-Mo bond are slight. In CAT, the bond length of Mo-Mo bond is $2.098 \AA$ and the Wiberg bond order is 3.18. As the reaction proceeding, the Mo-Mo bond length increases a little. In PCl, the Wiberg bond order of Mo-Mo bond (3.23) is slightly larger than that in CAT.

Second $\mathrm{C}$ - $\mathrm{Cl}$ bond activation: The second step also begins at the $\mathrm{Cl}$ atom of $\mathrm{CCl}_{4}$ attacking the $\mathrm{Mo}$ atom of $\mathrm{PCl}$ to form the COM4. Then, this $\mathrm{Cl}$ atom links to $\mathrm{Mo}$ atom and pushes the $\mathrm{Cl}$ atom in $\mathrm{PC} 1$ to another Mo atom through TS3 to form $\left[\mathrm{Mo}_{2}\left(\mathrm{CH}_{3} \mathrm{NCHNCH}_{3}\right)_{3} \mathrm{Cl}_{2}\right](\mathrm{PCl} 2)$ and $\mathrm{CCl}_{3}$ radical. As shown in Figure 2(2), the $\triangle G^{\#}$ of TS3 is only $1.6 \mathrm{kcal} / \mathrm{mol}$ and the energy of TS3 is lower than the sum energy of separated reactants $\mathrm{PCl}$ and $\mathrm{CCl}_{4}$, meaning this step can occur easily. In PCl2, the Mo-Mo bond order decreases to 2.69 .

$\mathrm{CCl}_{3}$ addition to 1-hexene: The dissociated $\cdot \mathrm{CCl}_{3}$ radical attacks the $\mathrm{C} 1$ atom of 1-hexene with a energy barrier of $9.0 \mathrm{kcal} / \mathrm{mol}$ (Fig. 3). In this reaction process, the spin electron density migrates from the $\mathrm{C}$ atom of $\mathrm{CCl}_{3}$ radical to the $\mathrm{C} 1$ atom of 1-hexene, $\mathrm{COM7}$ forms. This step has been discussed in our former work [8].

$\mathrm{Cl}$ atom migration and $\left[\mathrm{Mo}_{2} \mathrm{~L}_{3} \mathrm{Cl}\right]$ regeneration: The last step of the reaction is the $\mathrm{C} 2$ atom of COM7 interacts with one $\mathrm{Cl}$ atom of $\mathrm{PCl} 2$, the $\mathrm{Cl}$ atom migrates from Mo atom to $\mathrm{C} 2$ atom via TS5. After TS5, 
COM9 forms, then it separates to Product (Pro) 1, 1, 1, 3-tetrachloroheptane and PCl. The $\Delta G^{\#}$ of this step is $16.2 \mathrm{kcal} / \mathrm{mol}$.

In summary, the whole reaction pathway contains four steps. Among them, the first C-Cl bond activation process is the rate-determining step and it is not in the catalytic cycle. The catalytic cycle contains the second $\mathrm{C}$ - $\mathrm{Cl}$ bond activation, $\mathrm{CCl}_{3}$ radical addition to 1-hexene, $\mathrm{Cl}$ atom migration and $\left[\mathrm{Mo}_{2} \mathrm{~L}_{3} \mathrm{Cl}\right]$ regeneration processes. The $\Delta \mathrm{G}^{\#}$ of the first step are about $22.0 \mathrm{kcal} / \mathrm{mol}$, those of other three steps are within $20.0 \mathrm{kcal} / \mathrm{mol}$. Therefore, increasing the reaction temperature could accelerate the first C-Cl bond activation process, and the whole reaction would speed up after a certain period of time and not need the heating.

\subsection{Influences of ligands on the catalytic activity}

Based on the mechanism study, the first step is the rate-determining step, and the experimental results show that the catalytic activity is correlated to the redox potential of $\mathrm{Mo}_{2}{ }^{4+} / \mathrm{Mo}_{2}{ }^{5+}[4,27]$.In order to screen out the high activity catalyst, the electronic structures of $\left[\mathrm{Mo}_{2}\right]$ complexes with different ligands are calculated. The relationship between the electronic structure and the $\Delta \mathrm{G}^{\#}$ of the first step is found to determine how the ligand tuning the catalytic activity of $\mathrm{Mo}_{2} \mathrm{~L}_{4}$. The following catalysts are considered (Scheme 2).

The Gibbs energy barriers $\left(\Delta \mathrm{G}_{1}{ }^{\#}\right)$, redox potentials $\left(\mathrm{E}\left(\mathrm{Mo}_{2}{ }^{4+} / \mathrm{Mo}_{2}{ }^{5+}\right)\right)$ and natural population analysis charges of Mo atom of different catalysts are listed in Table 1. The redox potentials [39] are calculated as follow: Geometries were optimized in gas phase followed by single point energy calculations in solvent $\mathrm{CHCl}_{3}$. Solvation was modelled by the polarized continuum model (PCM). The Gibbs free energies of the redox reaction in $\mathrm{CHCl}_{3}$ were calculated as follows:

$\Delta \mathrm{G}_{\text {solv }}=\Delta \mathrm{G}_{\text {solv }}\left(\mathrm{Mo}_{2}{ }^{4+}\right)-\Delta \mathrm{G}_{\text {solv }}\left(\mathrm{Mo}_{2}{ }^{5+}\right)$

Then the calculated Gibbs free energies were converted to absolute electron redox potential according to Nernst equation:

$\Delta \mathrm{G}_{\text {solv }}=-\mathrm{FE}\left(\mathrm{Mo}_{2}{ }^{4+} / \mathrm{Mo}_{2}{ }^{5+}\right)(2)$

where $\mathrm{F}$ is the Faraday constant, $96500 \mathrm{C} \cdot \mathrm{mol}^{-1}$.

Comparing the redox potential of $\mathrm{Mo}_{2}\left(\mathrm{CH}_{3} \mathrm{NCHNCH}_{3}\right)_{4}$ with those of mixed-ligated $\left[\mathrm{Mo}_{2}\right]$ catalysts, it can be seen that the $\mathrm{E}\left(\mathrm{Mo}_{2}{ }^{4+} / \mathrm{Mo}_{2}{ }^{5+}\right)$ of $\mathrm{Mo}_{2}\left(\mathrm{CH}_{3} \mathrm{NCHNCH}_{3}\right)_{4}$ is the lowest. As one $\mathrm{CH}_{3} \mathrm{NCHNCH}_{3}$ ligand is substituted by $\mathrm{OCO}(\mathrm{R})\left(\mathrm{R}=\mathrm{CH}_{3}\right.$, 3-py, 4-py, ph, Furan), the redox potential of $\mathrm{E}\left(\mathrm{Mo}_{2}{ }^{4+} / \mathrm{Mo}_{2}{ }^{5+}\right)$ increases distinctly. Moreover, the NPA charges of Mo atoms are also increased. The more positive charge of Mo atom will facilitate the attacking of $\mathrm{Mo}$ to $\mathrm{Cl}$ of $\mathrm{CCl}_{4}$ with negative charge. Thus, the catalytic activities of 
mixed-ligated $\left[\mathrm{Mo}_{2}\right]$ catalysts are higher than those of homoleptic. The $\mathrm{R}$ in the ligands has little influence on the activity.

In total, the catalytic activity is correlated to the redox potential of $\mathrm{E}\left(\mathrm{Mo}_{2}{ }^{4+} / \mathrm{Mo}_{2}{ }^{5+}\right)$ and NPA charge of Mo. The higher $\mathrm{E}\left(\mathrm{Mo}_{2}{ }^{4+} / \mathrm{Mo}_{2}{ }^{5+}\right)$ and NPA charge of the catalyst, the higher activity it has.

\section{Conclusions}

The detailed catalytic mechanism of a series of paddlewheel complexes $\left[\mathrm{Mo}_{2} \mathrm{~L}_{4}\right]$ featuring Mo-Mo quadruply-bond with different ligands on radical addition of $\mathrm{CCl}_{4}$ to 1-hexene was investigated. The following conclusions can be drawn:

- The Mo-Mo quadruply-bond paddlewheel complexes are good catalysts on the radical addition reaction of $\mathrm{CCl}_{4}$ to 1-hexene.

- The whole reaction involves 4 steps. The addition of the first $\mathrm{CCl}_{4}$ is the rate-determining step of the whole reaction; the reaction would speed up after a certain period of time.

- The catalytic activity of dimolybdenum paddlewheel complex is depended on the natural population analysis (NPA) charge of Mo and the redox potential $\mathrm{E}\left(\mathrm{Mo}^{4+} / \mathrm{Mo}^{5+}\right)$. The higher $\mathrm{E}\left(\mathrm{Mo}_{2}{ }^{4+} / \mathrm{Mo}_{2}{ }^{5+}\right)$ and NPA charge of the catalyst, the higher activity it has.

\section{Declarations}

\section{ASSOCIATED CONTENT}

Supporting Information. The following files are available free of charge. Calculated Gibbs free energy and $\mathrm{XYZ}$ coordinates of the stable points.

Declarations

Funding Sources

This work was supported by National Natural Science Foundation of China (Contract Nos. 21973027, 21973025), Natural Science Foundation of Hebei Province (Contract No. B2020205002, B2019205061, B2018205198).

Conflict of interest

The authors declare that they have no conflict of interest.

Author Contributions

The manuscript was written through contributions of all authors. All authors have given approval to the final version of the manuscript. 
Notes

The authors declare no competing financial interest.

\section{References}

1.Lawton D, Mason R(1965) J Am Chem Soc 87: 921-922.

2.Cotton FA, Donahue JP, Gruhn NE, Lichtenberger DL, Murillo CA, Timmons DJ, VanDorn O, Villagrán D, Wang X(2006) Inorg Chem 45: 201-213.

3.Cotton FA, Murillo CA, Wang X, Wilkinson CC(2006) Inorg Chem 45:5493-5500.

4.Tsurugi H, Yamada K, Majumdar M, Sugin Y, Hayakawa A, Mashima K(2011) Dalton Trans 40: 93589361.

5.Brogden DW, Berry JF(2015) Inorg Chem 54: 7660-7665.

6.Noor A, Wagner FR, Kempe R(2008) Angew Chem 120: 7356-7359.

7.Huang YL, Lu DY, Yu HC, Yu JSK, Hsu CW, Kuo TS, Lee GH, Wang Y, Yi-Chou Tsai,YC(2012) Angew Chem 124: 901-7905.

8.Kang LX, Huo SH, Meng LP, Li XY(2020) Appl Organomet Chem 34:e5726.

9.Cotton FA, Murillo CA, Walton RA, Walton RA(2005) Springer Science and Business Media, Springer Science and Business Media, Inc.

10.Doyle MP, Duffy R, Ratnikov M, Zhou L (2010) Chem Rev 110:704-724.

11.Chisholm MH, Lear BJ(2011) Chem Soc Rev 40: 5254.

12.Berry J(2010) Metal-Metal Bonding, Parkin, G., Springer, pp. 1-28.

13.Filatov AS, Petrukhina MA(2010) Coord Chem Rev 254:2234-2246.

14.Timmer GH, Berry JF(2012) Chem Sci 3: 3038.

15.Hansen J, Davies HML(2008) Coord Chem Rev 252:545-555.

16.Yamashita Y, Salter MM, Aoyama K, Kobayashi S(2006) Angew Chem Int Ed 45:3816-3819.

17.Cotton FA, Feng X(1997) J Am Chem Soc 119: 7514-7520.

18.Tsurugi H, Hayakawa A, Kando S, Sugino Y, Mashima K(2015) Chem Sci 6:3434-3439. 
19.Knöfel ND, Schweigert C, Feuerstein TJ, Schoo C, Reinfandt N, Unterreiner AN, Roesky PW(2018) Inorg Chem 57: 9364-9375.

20.Carrasco M, Curado N, Álvarez E, Maya C, Peloso R, Poveda, ML, Rodríguez A, Ruiz E, Álvarez S, Carmona E(2014) Chem Eur J 20: 6092 - 6102.

21.Chisholm MH(2013) Coord Chem Rev 257:1576-1583.

22.Cotton FA, Daniels LM, Hillard EA, Murillo CA(2002) Inorg Chem 41:1639-1644.

23.Cotton FA(1983) J Chem Educ 60: 713.

24.Rej S, Majumdar M, Kando S, Sugino Y, Tsurugi H, Mashima K(2016) Inorg Chem 56: 634-644.

25.Rej S, Tsurugi H, Mashima K(2018) Coord Chem Rev 355:223-239.

26.Cotton FA, Daniels LM, Murillo CA, Timmons DJ, Wilkinson CC(2002) J Am Chem Soc 124:9249-9256.

27.Hicks J, Ring SP, Patmore NJ(2012) Dalton Trans.41:6641.

28.Perdew JP, Burke K, Ernzerhof M(1996) Phys Rev Lett 77:3865-3868.

29.Perdew JP, Burke K, Ernzerhof M(1997) Phys Rev Lett 78:1396-1396.

30.Weigend F, Ahlrichs R(2005) Phys Chem Chem Phys 7:3297-3305.

31.Weigend F (2005) Phys Chem Chem Phys 8: 1057-1065.

32. Frisch MJ, Trucks GW, Schlegel HB, Scuseria GE, Robb MA, Cheeseman JR, Scalmani G, Barone V, Mennucci B, Petersson GA, Nakatsuji H, Caricato M, Li X, Hratchian HP, Izmaylov AF, Bloino J, Zheng G, Sonnenberg JL, Hada M, Ehara M, Toyota K, Fukuda R, Hasegawa J, Ishida M, Nakajima T, Honda Y, Kitao O, Nakai H, Vreven T, Montgomery JA Jr, Peralta JE, Ogliaro F, Bearpark M, Heyd JJ, Brothers E, Kudin KN, Staroverov VN, Kobayashi R, Normand J, Raghavachari K, Rendell A, Burant JC, lyengar SS, Tomasi J, Cossi M, Rega N, Millam JM, Klene M, Knox JE, Cross JB, Bakken V, Adamo C, Jaramillo J, Gomperts R, Stratmann RE, Yazyev O, Austin AJ, Cammi R, Pomelli C, Ochterski JW, Martin RL, Morokuma K, Zakrzewski VG, Voth GA, Salvador P, Dannenberg JJ, Dapprich S, Daniels AD, Farkas O, Foresman JB, Ortiz JV, Cioslowski J, Fox DJ (2013) Gaussian 09, revision D. 01. Gaussian, Inc., Wallingford CT.

33.Grimme S, Antony J, Ehrlich S, Krieg H(2010) J Chem Phys 132:154104.

34.Goerigk L, Grimme S(2011) Phys Chem Chem Phys 13: 6670-6688.

35.Schultz NE, Zhao Y, Truhlar DG(2005) J Phys Chem A 109:11127-11143.

36.Gonzalez C, Schlegel HB(1989) J Chem Phys 90:2154-2161. 
37.Gonzalez C, Schlegel HB(1990) J Phys Chem 94: 5523-5527.

38.Glendening E, Reed A, Carpenter J, Weinhold F(1990) NBO 3.1; Theoretical Chemistry Institute, University of Wisconsin: Madison, WI.

39.Varela-Álvarez A, Yang T, Jennings H, Kornecki KP, Macmillan SN, Lancaster KM, Mack JBC, Du Bois J, Berry JF, Musaev DG(2016) J Am Chem Soc 138:2327-2341.

\section{Table}

Table 1 Gibbs energy barrier $\left(\Delta G_{1}^{\#}\right.$, in $\left.\mathrm{kcal} / \mathrm{mol}\right)$, redox potential $\left(E\left(\mathrm{Mo}^{4+} / \mathrm{Mo}^{5+}\right)\right.$ in $\left.\mathrm{mV}\right)$ and natural population analysis (NPA) charge of Mo in different catalysts

\begin{tabular}{cccc}
\hline $\mathrm{Mo}_{2}$ Cat. & $\Delta G_{1}^{\#}$ & $E\left(\mathrm{Mo}^{4+} / \mathrm{Mo}^{5+}\right)$ & charge \\
\hline $\mathrm{Mo}_{2}\left(\mathrm{CH}_{3} \mathrm{NCHNCH}_{3}\right)_{4}$ & 25.4 & 337.0 & 0.495 \\
$\mathrm{Mo}_{2}\left(\mathrm{CH}_{3} \mathrm{NCHNCH}_{3}\right)_{3}\left(\mathrm{OCO}\left(\mathrm{CH}_{3}\right)\right)$ & 21.0 & 425.4 & 0.587 \\
$\mathrm{Mo}_{2}\left(\mathrm{CH}_{3} \mathrm{NCHNCH}_{3}\right)_{3}(\mathrm{OCO}(3-\mathrm{py}))$ & 20.2 & 1603.6 & 0.600 \\
$\mathrm{Mo}_{2}\left(\mathrm{CH}_{3} \mathrm{NCHNCH}_{3}\right)_{3}(\mathrm{OCO}(4-\mathrm{py}))$ & 19.2 & 1754.2 & 0.605 \\
$\mathrm{Mo}_{2}\left(\mathrm{CH}_{3} \mathrm{NCHNCH}_{3}\right)_{3}(\mathrm{OCO}(\mathrm{Ph}))$ & 20.8 & 1153.9 & 0.598 \\
$\mathrm{Mo}_{2}\left(\mathrm{CH}_{3} \mathrm{NCHNCH}_{3}\right)_{3}(\mathrm{OCO}(2-\mathrm{Furan}))$ & 21.7 & 907.3 & 0.596 \\
\hline
\end{tabular}

$\mathrm{Ph}=\mathrm{C}_{6} \mathrm{H}_{5}, \mathrm{Py}=\mathrm{C}_{5} \mathrm{H}_{5} \mathrm{~N}$, Furan $=\mathrm{C}_{4} \mathrm{H}_{4} \mathrm{O}$.

\section{Figures}




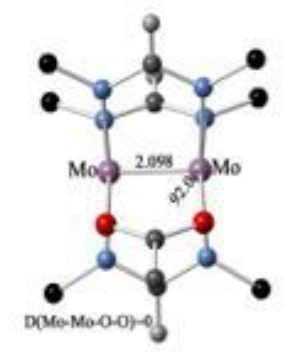

CAT

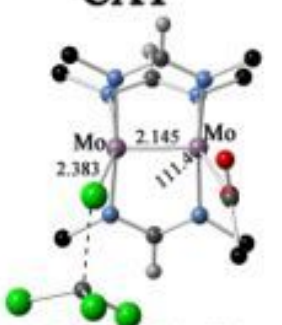

D(Mo-Mo-0-0)--73.8

COM2

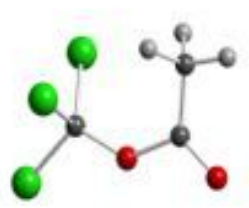

\section{$\mathrm{H}_{3} \mathrm{COOCCl}_{3}$}

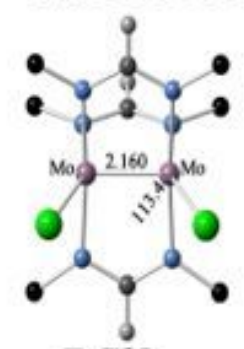

PC12

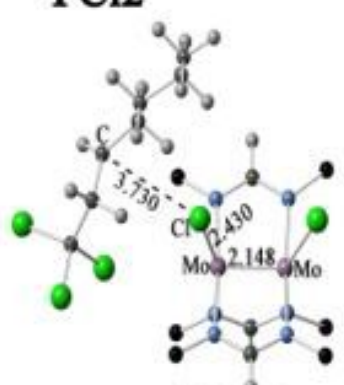

COM8

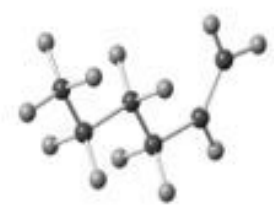

1-hexene

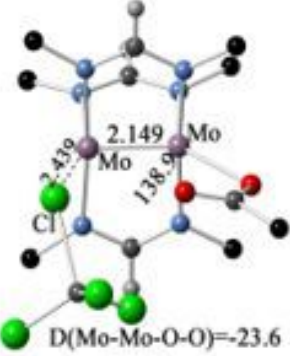

TS2

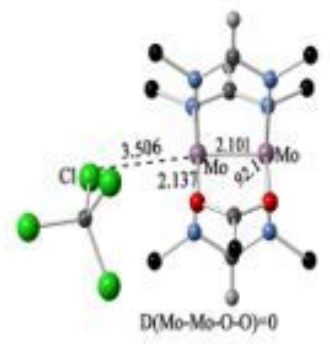

COM1

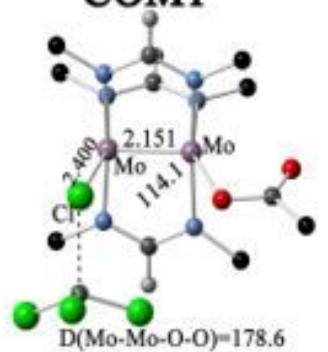

COM3

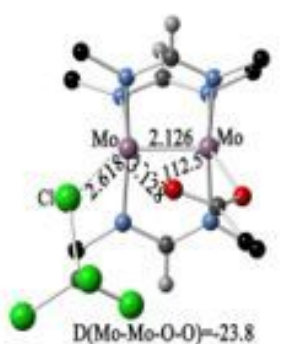

TS1

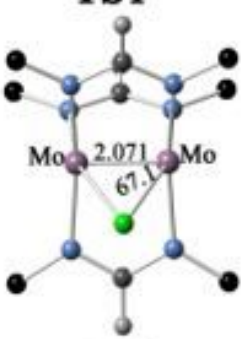

$\mathrm{PCl}$

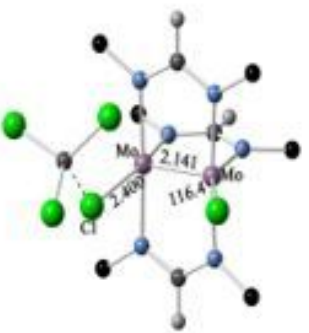

COM5

TS3

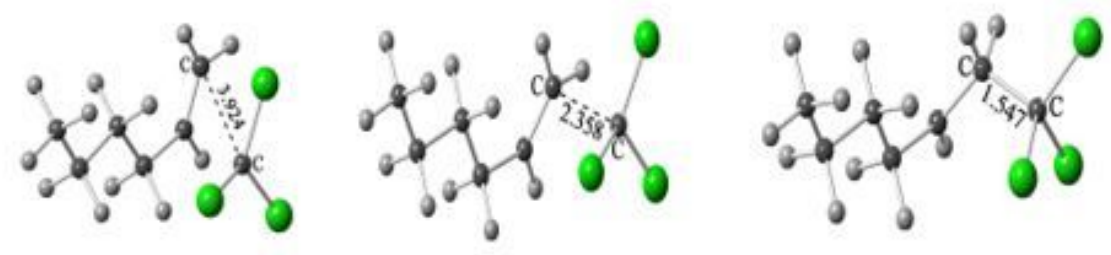

COM6

TS4

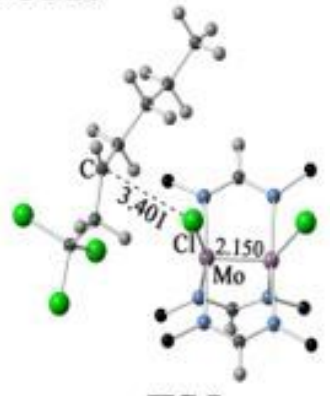

TS5

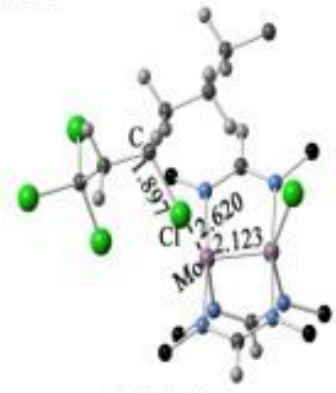

COM9
COM7

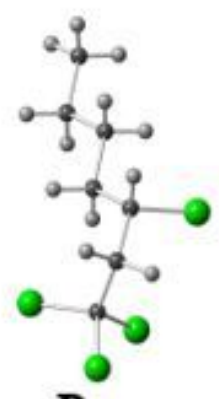

Pro

Figure 1

Geometries and key bond lengths (in $\AA$ ) of stationary points on PES 


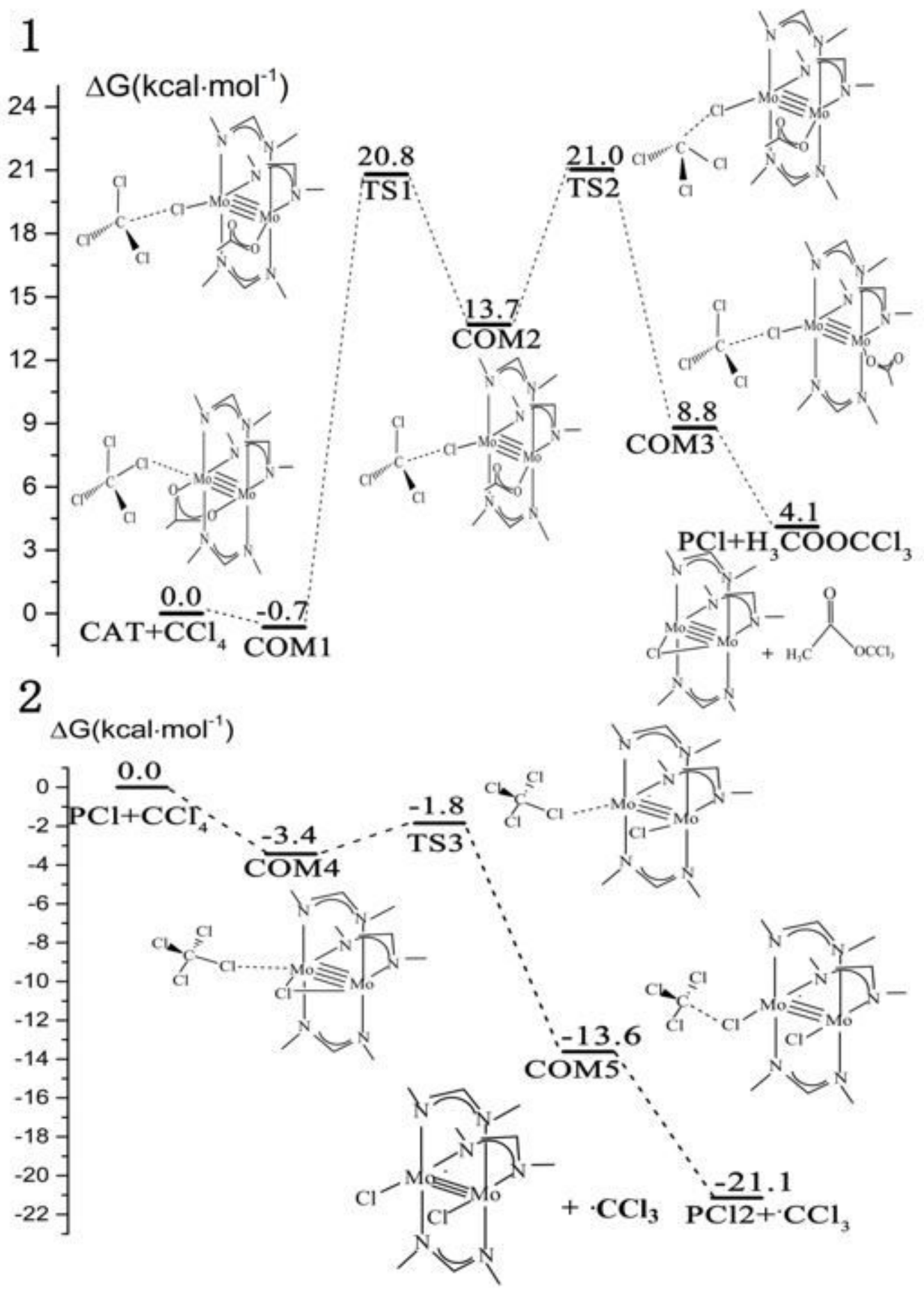

Figure 2

Potential energy surfaces of the $\mathrm{C}$ - $\mathrm{Cl}$ bond activation 

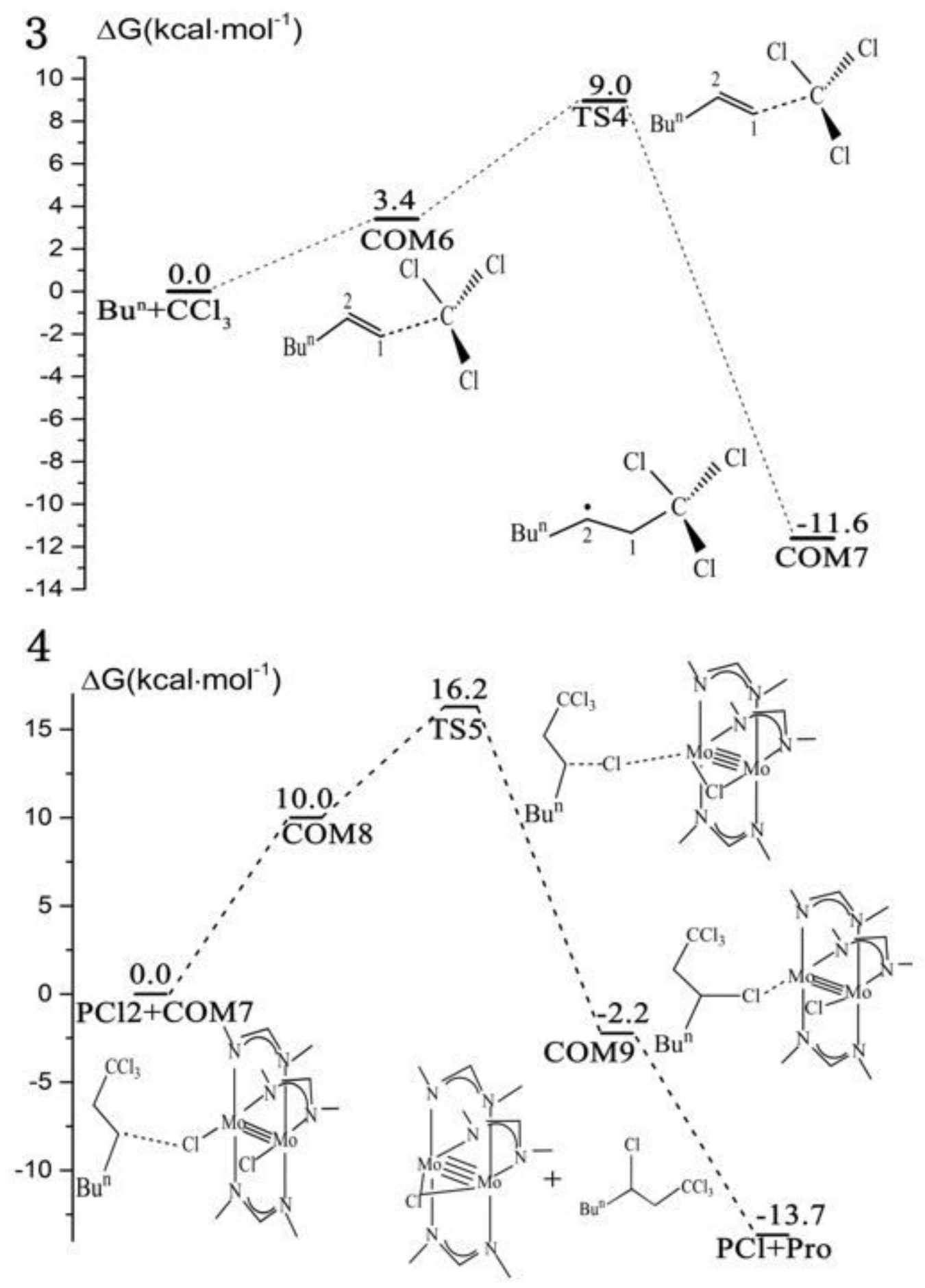

Figure 3

Potential energy surfaces of the addition reactions

\section{Supplementary Files}

This is a list of supplementary files associated with this preprint. Click to download. 
- supportinginformation.docx

Page 13/13 